【カテゴリーI】

\title{
長岡市の大正時代中期における上水道計画について \\ STUDY ON THE WATERWORKS PLAN IN THE MIDDLE \\ OF TAISYO ERA OF NAGAOKA CITY
}

\author{
平山育男* \\ Ikuo HIRAYAMA
}

\begin{abstract}
This article considered the waterworks plan of finished Nagaoka city by about 1919. This document is waterworks plan of 1920 when the details were not clear until now. This plan was made by Jiro Inoue. The plan of 1922 changed the technical and budget problems of the plan in 1920. The reason why the waterworks plan of Nagaoka in 1920 was asked Inoue for was that he had the abundant results of the waterworks laying in cold districts and he was freelance in those days.
\end{abstract}

Keywords : waterworks plan, Jiro Inoue, Nagaoka city 上水道計画, 井上二郎, 長岡市

\section{1. はじめに}

長岡市における上下水道の敷設は明治34(1901) 年に上水道、明治 $36(1903)$ 年と大正 $2(1913)$ 年に下水道、大正 $9(1920)$ 年に再び上水 道の計画(以下、大正 $9(1920)$ 年計画)があったものの、最終的には 大正11(1922) 年に至り、中島鋭治が上水道、鶴見一之が下水道を計 画したもの (以下、大正 11(1922) 年計画) が実施に至り、昭和 2 (1927) 年に上下水道が同時に竣功した ${ }^{(i 1)}$ 。

近代の長岡市では低湿地が多い地形面の条件から上水道に加え下 水道の敷設も早くから要望されて両者の賛否が分かれ、上下水道の 敷設計画はいずれも3回ずつ練られた注2)。

このように長岡における上下水道の計画年次は従来から報告され ていたが、成案となり資料も公刊された大正 11(1922) 年計画注3)以 外、資料の散逸が考えられ注4) 内容はこれまで明らかとされていない。 ところで筆者はこの内、大正 9(1920)年計画と考えることのでき る大正時代中期の長岡市における上水道敷設設計資料を某書肆から 入手寸るに至り、その概要を既に明らかにしている注5)。但し、大正 $9(1920)$ 年計画自体がどのように進められ、どのような意味を持つも のであるのか、その考察はなされていない。そこで本稿においては 筆者が入手した長岡市における大正時代中期と考えられる一群の資 料の検討を通し、その制作年代と計画立案者、計画の背景などを明 らかにすること目的とする。

\section{2. 資料の概要}

入手した資料は

1)『長岡市上水道布設工事設計説明書 附 工事方法書』(以下、『説 明書』)

2)『長岡市上水道布設工事予算書』(以下、『予算書』)

3)『上水道比較水路取入口信濃川附近縦断面図』(以下、『縦断面図』)

4）『長岡市上水道配水場悠久山附近』(以下、『悠久山附近』) の図面

5）『水質試験』

6）『添付図面目録』

$7 ＼mathrm{~ 『(二) ~ 長 岡 市 現 在 井 水 口 質 調 』(以 下 、 『 井 水 口 質 調 』) ~}$

8)『六特殊工場二於ケル所要水量並二供給方法』(以下、『特殊供給』)

9)『長岡市上水道調查要項順序』(以下、『要項順序』)

10）『その他予算関連書類』(以下、『その他書類』)
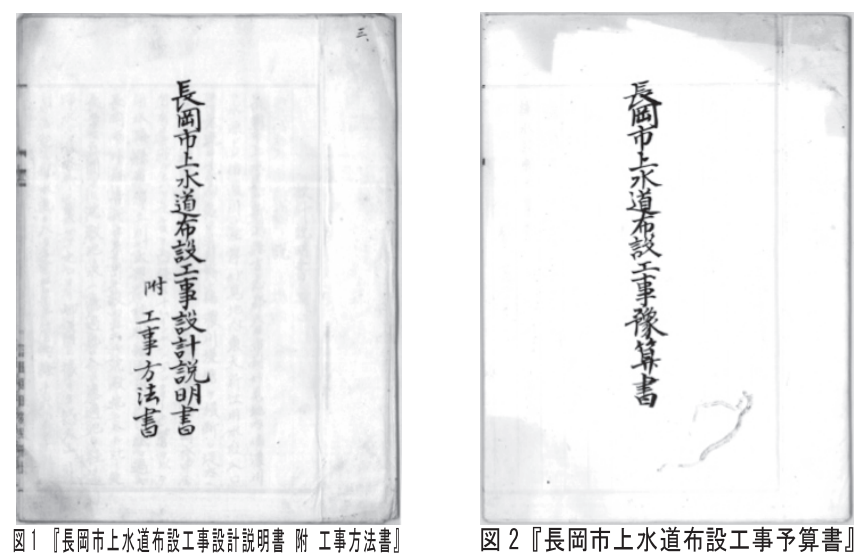

* 長岡造形大学造形学部 教授・博士 (工学)、博士(造形)

Prof., Faculty of Design, Nagaoka Institute of Design, Dr.Eng., Dr.Design 
11)『書簡』

12）『長岡市上水道布設工事予算書』(以下、『予算書下書』)

13)『長岡市上水道設計説明書』(以下、『説明書下書 $1 』)$

14) 『設計説明書』(以下、『説明書下書2』)

15)『雑書類一式』

からなる。各資料の書誌情報と内容は以下の通りである。

1)『長岡市上水道布設工事設計説明書 附 工事方法書』(図1)

資料はA4版で、表紙裏表紙を含め紙数 16 枚からなり、背が綴じら れる。用紙はA3 版よりやや小さい縦 $273 \mathrm{~mm} 、$ 横 $396 \mathrm{~mm}$ のつ折で、折目 中央に “富士製紙株式会社” と印刷され、A4各頁に12行、合計24行 の枠線が赤色で印刷される。表紙は毛筆で、内容はカーボン紙によ る転写とする。内容は “設計説明書” と題して “総説” 以下の詳細 が記され、制作年の記載はない。但し、1紙裏の “水源に於ける水量 及水質”において “水量は大正六年九月十日に観測” とする。また、 13 紙表の “長岡市最近十ヶ年戸数及人口調” の欄に大正 5 (1916) 年ま での人口等が掲載され、2紙裏における同年の人口を 41,135 人とし、 12 紙表から12紙裏の “長岡市人口増殖数” では大正6 (1917) 年から大 正25 (1936) 年までの人口を予測する。また、“給水量”の欄に“本 市八現在人口四一, 二三○人”とするため資料の作成は大正6 (1917) 年9月以後と考えられる。

2)『長岡市上水道布設工事予算書』(図2)

A4版で表紙裏表紙を含め紙数 18 枚からなり、背を綴じる。用紙は A3版よりやや小さい縦 $273 \mathrm{~mm}$ 、横 $396 \mathrm{~mm}$ のつ折で、“12 吉野屋製” と向かって左下にあり、A4各頁に 12 行の枠線が青色で印刷される。 表紙は毛筆、内容はカーボン紙による転写で、“総工事費”を筆頭 に以下、各工事内訳の詳細が記されるが、制作年の記載はない。

3)『上水道比較水路取入口信濃川附近縦断面図』

縦392mm、横 $1710 \mathrm{~mm}$ の美濃紙1紙に墨入される。1/200の縮尺で、上 水道比較水路取入口信濃川附近縦断面図が描かれる。なお、0尺レベ ルが朱筆、最低水位が水色で記される。制作年は記されない。

\section{4) 『長岡市上水道配水場悠久山附近』}

縦 $785 \mathrm{~mm}$ 、横 $1250 \mathrm{~mm}$ の美濃紙1紙に墨入される。1/1200の縮尺で、 長岡市上水道配水場悠久山附近の様子が描かれる。なお、題名と縮 尺が薄い朱色で影が付けられ、境界線が朱、道路が橙、水路が水色 で記される。制作年の記載はない。

\section{5）『水質試験』}

B4版よりやや小さい縦 $244 \mathrm{~mm}$ 、横 $331 \mathrm{~mm}$ のつ折で、紙数 1 枚からな り、横に4つ折りされた痕が残る。用紙はB55版となる各頁に12行、合 計24行の枠線が青色で印刷される。毛筆で吉村駒蔵による水質試験 の結果が大正8(1919)年3月2日付で記載される。なお、吉村は長岡市 千手にて薬品を取り扱った商標、吉駒の経営者である注6)。

\section{6)『添付図面目録』}

B5版よりやや大きい縦 $260 \mathrm{~mm}$ 、横 $186 \mathrm{~m}$ で紙数 2 枚からなる。用紙は 向かって右上に“大正年月 日”、向かって右下に“富士製紙株式 会社札幌事務所”、向かって左上に“札幌”、向かって下に“北一 条東一丁目四番地 電話一四五八番” と印刷され、12行の枠線が黒色 で印刷される。内容は毛筆により、添付図面の目録が記され記され る。制作年の記載はない。

\section{7) 『(二)長岡市現在井水口質調』}

B4版よりやや小さい縦 $251 \mathrm{~mm}$ 、横 $338 \mathrm{~mm}$ の 2 つ折用紙17枚と、最後の 1紙は半分の大きさに裁断した向かって右側を使う合計18紙の資料 である。紙縒穴が1ケ所開けられるが、紙縒は現存しない。用紙はB5 版となる各頁に12行、1枚に合計24行の枠線が赤色で印刷され、中央 に“長岡市役所”と印刷される。ペン書で15紙以後は記載がない。 また、向かって右上に14紙まで番号が付される。“(二) 長岡市現在 井水口質調” 以下、“三、長岡市最近十ヶ年戸数人口調”などが記 載されるが、項目立ては後掲の9）『要項順序』に則る。制作年の記 載はないが、“(二)長岡市現在井水々質調”では大正3 (1914) 年の資 料、“三、長岡市最近十ヶ年戸数人口調”では明治40 (1907) 年から 大正5 (1916) 年までの資料、“十八、消防用井戸湧水量”では明治 42 (1909) 年の資料を用いるため、本書類自体は大正6 (1917) 年以後の 作成と判断できる。また、“四 流行病防護費”の欄には “明治四十 四年度ヨリ大正四年度迄五ヶ年間一一, 九二五円”とある。

\section{8）『六 特殊工場二於ヶル所要水量並二供給方法』}

B4版よりやや小さい縦 $250 \mathrm{~mm}$ 、横 $338 \mathrm{~mm}$ のつ折用紙1枚からなり、 縦に4つ折の痕がある。また、用紙向かって右側に紙縒穴が1ケ所開 けられるが、紙縒は現存しない。用紙はB55版各頁に12行、1枚に合計 24行の枠線が赤色で印刷され、中央に “長岡市役所”之印刷され、 ペン書きとする。内容は特殊工場における所要水量並びに供給方法 を記すが、表題冒頭の “六” は次項9）『要項順序』の項目立てによ り、制作年の記載はない。

9)『長岡市上水道調査要項順序』

表 1 資料の一覧

\begin{tabular}{|c|c|c|c|c|c|c|}
\hline 番号 & 表題 & 略称 & 紙数 & 記載内容 & 年代 & 備考 \\
\hline 1) & 長岡市上水道布設工事設計説明書 附 工事方法書 & 説明書 & 16紙 & 工事説明 & 大正5(1916)年までの資料 & \\
\hline 2) & 長岡市上水道布設工事予算書 & 予算書 & 18紙 & 予算 & - & \\
\hline 3) & 上水道比較水路取入口信濃川附近縦断面図 & 縱断面図 & 1紙 & 縦断面図 & - & \\
\hline 4) & 長岡市上水道配水場悠久山附近 & 悠久山附近 & 1 紙 & 悠久山附近の平面図 & - & \\
\hline 5) & 水質試験 & - & 1 紙 & 水質試験 & 大正8(1919).3/2調査 & \\
\hline 6) & 添付図面目録 & - & 2紙 & 添付図面の目録 & - & \\
\hline 7) & (二)長岡市現在井水口質調 & 井水口質調 & 18紙 & 調査要項項目の調査内容 & \begin{tabular}{|l} 
明治42(1909)年, 大正3(1914)年の \\
資料及び大正5(1916)年までの資料
\end{tabular} & 9)に基づく書類の一部 \\
\hline 8) & 六 特種工場二於ケル所用水量並二供給方法 & 特種供給 & 1紙 & 調査要項項目の調査内容 & - & 9)に基づく書類の一部 \\
\hline 9) & 長岡市上水道調査要項順序 & 要項順序 & 2紙 & 調査要項の項目 & - & \\
\hline 10) & その他予算関連書類 & - & 7 紙 & 予算関連書類他 & $\begin{array}{l}\text { 10/,12/1,1/31,8/,9.10/,11/,12/,1/,2/ } \\
\text {,3/,4/,5/の記載 }\end{array}$ & \\
\hline 11) & 書簡 & - & 2紙 & 書簡 & 6/19の記載 & \\
\hline 12) & 長岡市上水道布設工事予算書 & 予算書下書 & 15紙 & 予算書の下書 & - & 2)の下書 \\
\hline 13) & 長岡市上水道設計説明書 & 説明書下書1 & 17紙 & 説明書の下書 & - & 一部に1)の下書 \\
\hline 14) & 設計説明書 & 説明書下書2 & 11 紙 & 説明書の下書 & 大正5(1916)年までの資料 & 1)“設計説明書”の下書 \\
\hline 15) & 雑書類一式 & - & 19紙 & 書簡、調査要項下書など雑書類 & “六年度分”,7/15,1/24,3/3の記載 & 9·10,11·12紙は9)の下書 \\
\hline
\end{tabular}

注記: 網掛けの1)〜4) が正本の設計書書類と判断できる 
B4版よりやや小さい縦 $249 \mathrm{~mm}$ 、横 $335 \mathrm{~mm}$ のつ折用紙1枚と、B5版よ りやや小さい縦 $245 \mathrm{~mm}$ 、横 $165 \mathrm{~mm}$ の用紙1枚の合計2枚からなり、向か って右側に紙縒穴3个所があるものの、紙縒は現存しない。B4版用紙 はB5版各頁に12行、1枚に合計24行の枠線が赤色で印刷され、中央に “長岡市役所”と印刷される。B5版用紙は12行の枠線が赤色で印刷 され、向かって右下に “長岡市役所” と印刷され、内容はペン書と する。上水道調查の要項順序が23項目記さており、制作年の記載は ない。

\section{0）『その他予算関連書類』}

B5版よりやや小さい縦 $243 \mathrm{~mm}$ 、横 $166 \mathrm{~mm}$ の用紙7枚を用い、向かって 右側に紙縒穴が1ケ所開けられるが、紙縒は現存しない。用紙には12 行の枠線が赤色で印刷され、向かって右下に “長岡市役所”と印刷 される。“調查材料蒐集追加 “ “トレースノ上送ルベキモノ” と題 され各1枚がカーボン紙による転写とする。その他 5 枚は表題を欠く 支払及び予定関係の書類4枚と “市会議員” と題される硬筆書である。 いずれも制作年の記載はないが、支払関係の書類に “八月廿五 日”“九月” “十月”“十二月一日”、“一月三十一日迄支払額”、 予定関係の書類に “八月 測量準備一回” “九、十月外業測 量” “十一月内業測量製図一回” “十二月設計材料蒐集” “一 月設計製図一回” “二月”一回” “三月 $"$ 一回” “四月

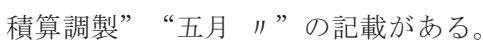

\section{1)『書簡』}

B5版よりやや小さい縦 $246 \mathrm{~mm}$ 、横 $168 \mathrm{~mm}$ の用紙2枚からなり、向かっ て右上が紙縒で綴じられる。用紙には表裏に12行の枠線が赤色で印 刷され、表は向かって左下、裏は向かって右下に “長岡市役所” と 印刷される。書簡、送付図面とその枚数が記される。内容はペン書 で、制作年の記載はないが “六月十九日”の記載がある。

\section{2）『長岡市上水道布設工事予算書』}

B5版よりやや大きい縦 $250 \mathrm{~mm}$ 、横 $189 \mathrm{~mm}$ の用紙2枚、B4版よりやや小 さい縦 $243 \mathrm{~mm}$ 、横 $328 \mathrm{~mm}$ のつ折用紙12枚、B5版よりやや小さい縦 $190 \mathrm{~mm}$ 、 横 $262 \mathrm{~mm}$ の用紙 (横置) 1 枚の合計15紙からなり、用紙は向かって右上 をクリップ止とする。B5版の用紙は12行の枠線が青色で印刷され、 向かって右下に“東京市京橋区三十間堀一丁目一番地 電話京橋 (長) 一三三番一三四番一三五番 (長)一一三二番二五八一番二七七三番二 七七四番 電略 (フジ)振替貯金東京九七九一番“、向かって左上に“大 正年月日”、向かって左下に“富士製紙株式会社” と印刷される。 B4版の用紙はB55版各頁に12行の枠線が青色で印刷され、B4版の向か って左下に “12 滝和屋製”と印刷される。また、最後の1紙はノー 卜様の紙を横使いで、28行の青線が引かれる。内容から2)『予算書』 の下書きと考えられる。ペン書であるが一部に硬筆書の部分があり、 制作年の記載はない。

\section{3）『長岡市上水道設計説明書』}

17 枚からなる資料で、B4版変型で縦 $261 \mathrm{~mm}$ 、横 $362 \mathrm{~mm} の$ 用紙 $2 つ$ 折の 16枚と、10紙目に半分の大きさの用紙1枚から構成される。用紙は向 かって右側に2穴を開けて紙縒で経り、更に3ケ所に鳩目金具を取り 付ける。B4版用紙は各頁縦25マス、横12行からなる原稿用紙で、羁 線は青色で印刷され、用紙向かって左下に “12 25 中村製” と記さ れる。B5版の用紙は 12 行の枠線が青色で印刷され、向かって右下に “北見国常呂郡野付町八百二十番地/電話一四○番/電略 (ノサ)”、 向かって左下に “富士製紙株式会社野付牛山林派出所” と印刷され
る。一部が1）『説明書』の下書となっており、記載はペン書、一部 硬筆書によるもので、制作年の記載はなされない。

\section{4）『設計説明書』}

B5版の変型で縦 $251 \mathrm{~mm}$ 、横 $189 \mathrm{~mm}$ の用紙11枚からなり、用紙は向か って右側を紙縒で経る。用紙は12)『予算書下書』と同じ “富士製紙 株式会社」”のものである。1）『説明書』の下書で、内容は硬筆書 とする。制作年の記載はないが、3紙目に“本市八現在人口四一, 二 三○人”とする1）『説明書』と同様の記載があり、大正6 (1917) 年以 後と考えられる。

\section{5）『雑書類一式』}

19紙からなり向かって右上を紙経で綴じる。1～3紙が縦 $208 \mathrm{~mm}$ 、横 $125 \mathrm{~mm}$ で11行の縦線が破線で記され、向かって上左に“No.”、向か って右上に“月日”といずれも青色で印刷される。4紙目は縦 $231 \mathrm{~mm} 、$ 横 $159 \mathrm{~mm}$ で10行の縦線が破線と実線で引かれ、向かって左上に“No.”、 向かって右上に“年 月 日”がいずれも青色で印刷される。5紙目 はB5版よりやや小さい縦 $243 \mathrm{~mm}$ 、横148mmの用紙で12行の縦線が実線 で引かれ、向かって右下に “長岡市役所”といずれも赤色で印刷さ れる。6紙目はB4版よりやや小さい縦 $244 \mathrm{~mm} 、$ 横 $336 \mathrm{~mm} の 2 つ$ 折で、各 頁12行の縦線があり、用紙の中央に “長岡市役所”といずれも赤色 にて印刷される。7紙目は5 紙目と同じ用紙で、B5版よりやや小さく、 縦は $243 \mathrm{~mm}$ と同一であるが横は $164 \mathrm{~mm}$ とする。8紙目はA 3 版よりやや小 さい縦 $277 \mathrm{~mm}$ 、横 $398 \mathrm{~mm}$ のつ折で、各頁 12 行の縦線が引かれ、用紙の 中央に “長岡市役所”といずれも赤色にて印刷される。9 17紙が5 紙目と同じB5版よりやや小さい用紙で、9、10紙が向かって右側2 所に穴を開け紙縒で綴じる。18紙目は縦 $248 \mathrm{~mm}$ 、横 $334 \mathrm{~mm}$ の半紙を 2 つ折で用いる。19紙目は5紙目と同いB5版よりやや小さい用紙である。 内容は 1 3 紙目が書簡で黒青インク書とし、年号は欠くが “七月十 五日”付とする。4紙目は “打合事項” で青インク書とし、制作年の 記載はない。5紙目が “長岡市役所上水道調査部”から“井上技師” 宛ての書簡で黒インク書、日付の記載はない。6紙目が “上水道調査 費 六年度分”で毛筆書(図3)、7 紙目は “長岡市長河島良温”から“井 上二郎”あての書簡でカーボン紙による転写とし、年号は久くもの の “一月二十四日”付けを持つ(図4)。8紙目が覆土等の注意事項で 黒インクと一部硬筆書で、末尾に“三月三日返事ス”とのみある。9 〜 10紙目が “長岡市上水道調查要項順序” で、カーボン紙による転 写で一部紫色鉛筆書、11 12紙が “長岡市上水道調查要項順序” ある硬筆書で、内容から9）『要項順序』の下書と考えられる。13紙 以後は “長岡市上水道実查方針”とする硬筆書で、いずれも制作年 は記されない。

\section{3. 資料の作成年代}

上述のように資料には制作年がほとんど記載されないが、1）『説 明書』、7)『井水口質調』では “長岡市最近十ヶ年戸数及人口調” ではいずれも大正 5 (1916) 年までの数字を掲載することから大正 6 (1917) 年以後の制作と判断され、5)『水質試験』は、大正8 (1919) 年3月2日の年記を持つ。但し、これらだけからでは具体的な資料作 成時期の判断はできない。

ところで、15）『雑書類一式』の6紙目 “上水道調查費 六年度分” によると、“内訳”として“技師報酬及旅費”として“報酬”が一 ケ月100円で 8 ケ月分、“旅費”が “八月、十月、十二月、二月、三 
月ノ五回出張 東京ヨリ往復旅費及長岡滞在費ヨ含ム” として計上 がされることから、報酬及び旅費の算定は大正6 (1917) 年の8月から 翌年3月までの8ケ月についてと判断できる。そして、これに対応す るのが10）『その他書類』支払関係の書類における日付と考えられ、 “八月廿五日”“九月”“十月”“十二月一日”、“一月三十一日 迄支払額”、“八月 測量準備一回” “九、十月 外業測量” “十 一月内業測量製図一回” “十二月設計材料蒐集” “一月 設計 製図一回” “二月”一回” “三月 $"$ 一回” “四月 積算調

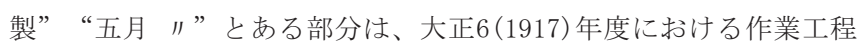
を示し、“四月 積算調製” “五月 $" ”$ は翌年度の大正7 (1918) 年度 の工程とすることができる。なお、大正6(1917) 年度各月末に記され る “一回” は5 ケ月、5回が記録され、これが15)『雑書類一式』“旅 費”に予定された技師の出張を示し、最終的に5）『水質試験』の水 質調查が大正8 (1919) 年3月2日にあったと考えられる。

以上より、資料が一連のものとすれば、資料群は大正6 (1917) 年8 月から調查に着手し、大正7 (1918) 年3月までに計画は立案され、こ れを受けて大正 7 (1918) 年4、5月に見積、大正 7 (1918) 年度末となる 3 月 2 日に水質調查の結果が出され、最終的に成案とされたとするのが 妥当である。つまり、本資料は従来から計画自体は指摘されている ものの、その内容や立案経緯が明らかではなかった長岡市における 大正 $9(1920)$ 年計画の書類と考えることができるのである。

\section{4. 資料の作成者}

\section{4-1 資料に見る作成者}

大正 $9(1920)$ 年計画については従来、作成者の名前は伝わらない。 但し、資料では15)『雑書類一式』5紙目に “井上技師”、7紙目に“井 上二郎”の名前を確認できる。また、用紙に1）『説明書』では“富 士製紙株式会社”、6）『添付図面目録』では“富士製紙株式会社札 幌事務所”との記載があることから、これらは富士製紙の社内用用 紙と判断できる。そして12)『予算書下書』と14)『説明書下書2』に は同じ “富士製紙株式会社” 東京支社における社内用用紙、13）『説
明書下書1』では “富士製紙株式会社野付牛山林派出所” の社内用用 紙を用いる。以上から、これらの資料は当時、富士製紙の関係者が 関わったとすることができよう。

この当時、富士製紙に関係した上水道関係者として挙げられるの は井上二郎である。井上については三谷和夫による研究注7)が既にあ る。これによると井上は明治 6 (1873) 年 10 月、茨城県藤代町の本陣 名主である横瀬家の次男として生まれ、東京帝国大学土木学科在学 中の明治 30 (1897) 年、千葉県布佐町の井上家へ養子に入った。井上 大学院修了後、明治 34(1901) 年 11 月、杤木県技師に任ぜられ、こ こでは鬼怒川、大谷川、日光百間堤の工事、京浜運河、鬼怒川水電 の調查設計に当たった。明治 41 (1908) 年 5 月には陸軍技師に転じ、 旭川、札幌などでの勤務をした後、大正 7 (1918) 年から富士製紙本 社技師、大正 9 (1920) 年からは富士電機土木部長、大正 12 (1923) 年 には北海道電灯株式会社土木部長を務めた。そして昭和 2 (1927) 年 2 月に会社を退き、以後は手賀沼の開拓事業に当たり、昭和 12 (1937) 年、69才で没したとする。この間、井上の関わった水道事業は、上 述した旭川注8)、札幌注9) の軍用水道等の敷設ほか、大正 5(1916) 年に は新潟県三条町 (当時) の上水道工事計画を立案し ${ }^{i \pm 10)}$ 、大正 6 (1917) 年 6 月から大正 10 (1921) 年 10 月の竣功まで福島県平町 (当時)にお ける上水道敷設の顧問技師に就いている注11)。また、後には新潟県 新津町、千葉県東金町（いずれも当時）において水道顧問注12) を勤 め、その敷設に関与した ${ }^{\text {注 } 13)}$ 。

4-2 新聞報道に見る調査の進行

一方、大正 6 (1917) 年の『新舄日報』紙では、8月 22 日号には

○長岡水源地視察

長岡市上水道技師工学士井上二郎氏は二十日保科土木技師と共 に上水道水源地調查として小千谷町へ出張し先づ小千谷町より 信濃川の上流川口まで視察し二十一日は二番上り列車にて高梨 に至り同地よりは妙見方面を視察し二十二日は悠久山方面を視 察すべし注14)

として(図 5)、井上二郎が小千谷、妙見、悠久山の地を大正 6 (1917)

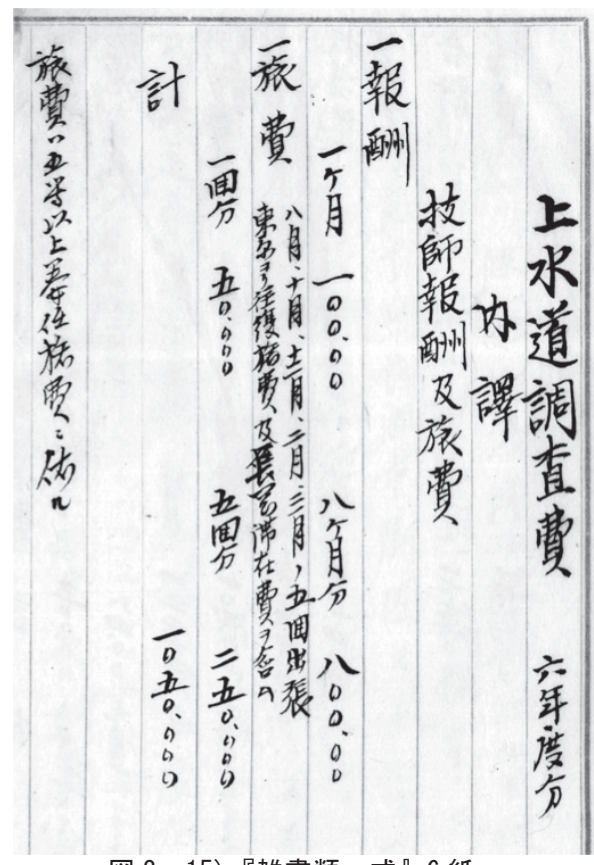

図 3 15) 『雑書類一式』6 紙

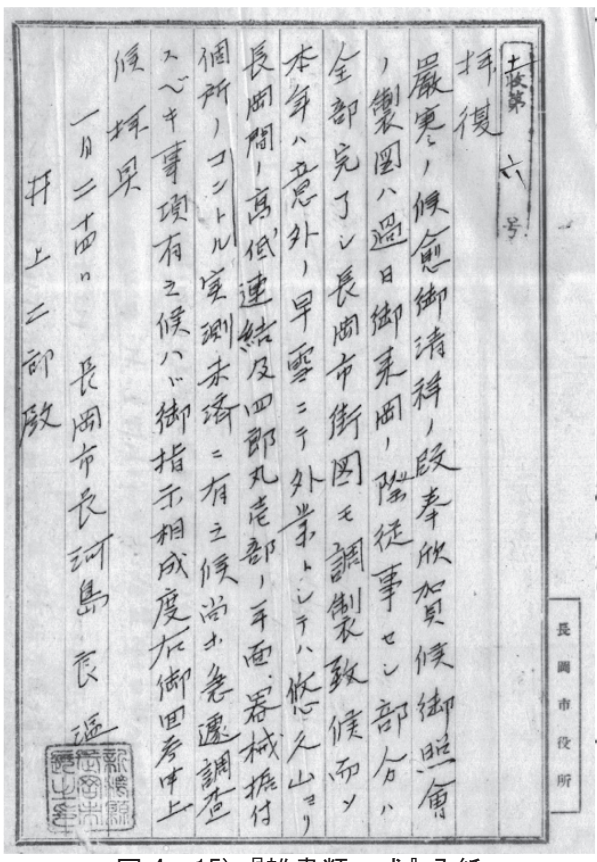

図 4 15) 『雑書類一式』7 紙

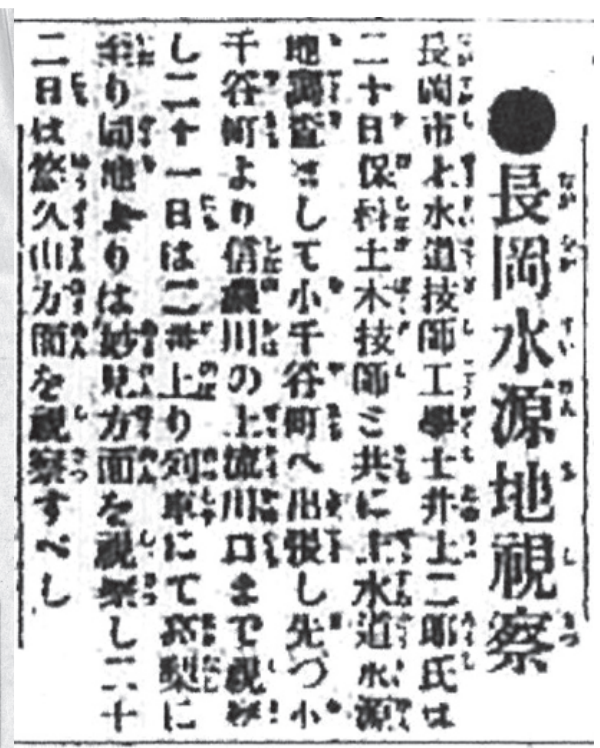

図 5 『新潟日報』大正 $6(1917) .8 / 22$ 
年 8 月 21 日から 3 日間に渡り視察したことを報道し、これは 10)『そ の他書類』における “八月 測量準備”に該当すると考えられる。な お、以後も井上による長岡周辺における測量等の様子が同紙におい て報道され、大正 6(1917) 年 9 月末から 11 月にかけては、妙見から 悠久山への測量を行い、作業は 11 月中旬には終了と伝えられる注15)。

\section{4-3 資料の作成者}

即ち、井上は本資料の作成時期である大正 6 (1917) 年 8 月から大 正 8(1919) 年 3 月の間、実際に長岡周辺の地も訪孔、長岡市におけ る上水道敷設計画を立案したことが判明する。

\section{5.『説明書』と『予算書』の構成}

大正 $9(1920)$ 年計画の 1$) 『$ 説明書』と2)『予算書』の書誌情報は上 述の通りである。以下に両資料の構成を挙げる。

1）『説明書』は冒頭に “設計説明書”とあり、“総説” 以下、“水 源二於ケル水量及水質” “給水量” “取入口及沈澱池” “導水管” “沈澱池、濾過池” “吸水井及唧筒” “配水池” “送水管” “配水 管” “水管橋” とする。続いて “工事方法書”として “取水口及水 閘工事” “沈砂池工事” “導水管工事” “沈澱池工事” “濾過池工 事” “汲水井及揚水機工事” “配水池工事” “送水管工事” “配水 工事” “長岡市人口増殖数” “長岡市最近十ヶ年戸数及人口調” “取 水口附近用水路各所要水量及灌洦反別”の項目からなる。

一方、大正 9 (1920) 年計画の 2$) 『$ 予算書』は “総工事費” “取水 口附近工事費” “沈砂池工事費” “導水路工事費” “沈澱池工事費” “濾過池工事費” “揚水設備工事費” “配水池工事費” “送水路工 事費” “配水路工事費” “玉石立一坪当リ工事費 (取水口用)” “「コ ンクリート」立一坪当リ工事費 (取水口用)” “野面石積及石張面一 坪当リ工事費 (取水口用)” “釜沢石一才当リ工事費” “「モルタル」 一切当リ工事費 (取水口用) ” “筋芝面一坪当リ工事費” “玉石一坪 当リ工事費 (沈澱池濾過池用)” “「コンクリート」立一坪当リ工事 費 (沈澱池濾過池用) ” “「モルタル」一切当リ工事費 (沈澱池濾過池 用)” “粘土立一坪当リ工事費 (沈澱池濾過地用)” “鉄管一間当リ敷 設工事費 (管径十六时十二时十吋分)” “鉄管一間当リ敷設工事費 (管 径八时六时四时分)” “「コンクリート」立一坪当リ工事費 (配水池 用)”“「モルタル」一切当リ工事費 (配水池用)” “釜沢石一才当リ 工事費 (配水池用)”の項目から構成される。

\section{6.『説明書』と『予算書』に見る大正 9 (1920) 年計画と大正 11 (1922) 年計画の相違}

大正 9 (1920) 年計画の概要は、1)『説明書』冒頭の “総説”に詳し い。これによると、計画において取水は現在の長岡市妙見の信濃川 から行い、これを堤防外の沈澱池に引き、コンクリート管により栖 吉に設けた濾過池へ導く。更に浄水は吸水井に集め、ポンプにより 悠久山前山に設ける配水池へ揚水し、鋳鉄管により弓町を通って市 街地一供給するものであった。

つまり、上の “総説” でも明らかなように、大正 9 (1920) 年計画で は、実施に至った大正11 (1922) 年計画とは以下に挙げる取水場所な どと、配水方法の2点で差異がある。次にこの 2 点に考察を加える。

\section{6-1 取水場所など}

大正 9(1920)年計画において、取水は 1)『説明書』“取水口及び 沈澱池”の項目に
取水口八東大新江取水口ノ下流約二十間ノ処ニシテ信濃川最大 渴水位二際シ推進一尺ヨ有シテ所用ノ水量ヨ引用シ得セシメ巾 三尺高五寸ノ半円穹蕯洪水閘卜セリ供水時二於ケル砂及夾雑物 ヨ沈澱セシムル為入沈澱池

テ所量水量

とある。つまり、大正 9(1920) 年計画では取水を信濃川の表流水に 求め、取水箇所は濾過池、配水池への送水落差を考慮し信濃川右岸 の妙見としている。

一方、敷設に至った大正 11(1922) 年計画で取水は “信濃川ノ河水 ノ沴透セル地下水” “注16)、即ち伏流水とし、取水場所を中島浄水場 に隣接する “古志郡川西村飛地内” 注17) と改めている。ところで表 流水の利用は、1）『説明書』“総説”に

沈澱池二入リ雪融ケ洪水ノ際二於ケル溷濁ノ河水中二包含スル 砂ヨ去リ

ともあるように、特に雪解けや洪水の場合は取水に含まれる土砂な どを除去するための沈砂池が必要で、濾過にも時間を要した。一方、 大正 11(1922) 年計画において取水は伏流水を集水埋渠により集め る方式が採られ、具体的には集水埋管を “地下約二十一尺ノ深サニ 埋設” 注18) した。このため “水源八取水口一体ノ砂利及砂層习浸透 シテ自然ノ濾過作用ヨナシタル地下水ナレ八概シテ清浄” 注19)なも のであった。因みにこの工法は中島鋭治が日本でははじめて採用し、 大正時代末頃から本格化したという注20)。つまり、大正 11(1924) 年 計画で沈砂池は設けられず、その分、建築費の削減も可能であった。

一方、取水場所の妙見は、現在の長岡市妙見浄水場の位置に重な るが、大正 $9(1920)$ 年計画がこの地に取水口を求めたのは、1)『説 明書』“導水管” の項目に

沈砂池ノ水量ヨリ沈澱池二至ル迄延長五, 七○○間二於テ信濃 川最大渇水位ヨ一○○尺トスレバ悠久山麓八九 $○$ 尺以下ニシテ

一○尺以下ノ落差ヨ有スルガ故自然流下ニヨリ沈澱池二導水ス とあるように、取水地の沈砂池から悠久山麓に設ける計画の沈澱池 まで自然流下を行うため、自然の落差を必要とするためであった。 但し、妙見より上流では導水にトンネル等も必要となるため、資金 的には妙見より下流で、しかも悠久山までの有効な落差を確保でき るこの地が取水には最適であった。しかし。“延長五, 七○○間”、即

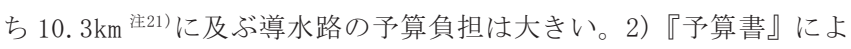
ると導水路工事費は 548, 508 円とあり、これは総工事費 220 万円の $25 \%$ にぶ゙注22)。つまり、大正 11 (1924) 年計画では取水地を“新潟 県古志郡川西村飛地内信濃川堤防二沿七堤内地下二集水埋管 シ同地及ビ長岡市下草生津町二亘り築造セル浄水場内低揚瑡筒井二 導流シ” 注23) とあるように、浄水場に隣接した直近の地に集水埋管 を埋設することによって、導水路の工事を最小限とし、その経費を 削減させたと見ることができる。

\section{6-2 配水方法}

配水池を市街地近くの高地に求める方法は当時の水道敷設工事に おける常法で、同時代に敷設された上水道事業では多くがその方法

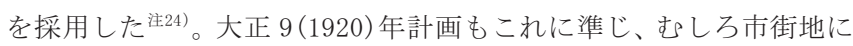
比較的近い悠久山に配水池を設けるため、前項で述べた妙見が取水 地に選ばれたとすることもできる。但し、大正 9(1920)年計画では 悠久山麓に濾過池を設けたものの、更に市街地への給水に際し、給 水末端における水頭圧を確保するため、濾過池より高所に配水池を 
設ける必要があった。具体的には 1)『説明書』“配水池” の項目に 配水池八悠久山地内二四九. 九尺ノ処二二個 7 築造ス

とされ、濾過池から配水池へ標高差 159.9 尺（約 $48.5 \mathrm{~m} ）$ の揚水に 濾過池ヨリ出テタル浄水八吸水井二集メ唧筒二依リテ配水池二 揚ゲ貯溜スルモノトス

とあるように、ポンプ施設は不可欠であった。

つまり、大正 $9(1920)$ 年計画では妙見の地から $10.3 \mathrm{~km}$ に及ぶ導水 路を建設して取水を悠久山へ導いても、配水に際しての水頭圧力が 確保できず、ポンプにより配水池へ揚水する設計とする点が、浄水 場に配水塔を用いた大正 11 (1922) 年計画注25) と異なる点であった。

\section{7. 大正 $9(1920)$ 年計画の問題点と大正 11 (1922) 年計画}

以上見てきたように大正 $9(1920)$ 年計画には種々の問題があった ことは明らかである。これを列挙すると

(1)取水方法 : 信濃川の表流水に求めた

(2)配水方法 : 悠久山に配水池を求めた

とする 2 点で、この 2 点は大正 11 (1922) 年計画との相違点でもある。 つまり、換言すれば大正 9(1920) 年計画の技術的な問題を改良する ことで大正 11 (1922) 年計画が立案されたと見ることができる。

一方、予算の観点から見ても両者には著しい相違がある。大正 9 (1920) 年計画の総予算は 220 万円であるが、実施の大正 11 (1922) 年計画は予算の段階である大正 11 (1922) 年においては 193 万円と見 積もられ ${ }^{\text {注26) }}$ 、単純に比較しても 27 万円安い。更に米価を基準に物 価を考慮すると大正 11(1922) 年計画は大正 6(1917) 年時点の 118 万 円に換算でき注27)、この值は大正 9 (1920) 年計画の総予算 220 万円に 対し 54\%の值となる。また、差額となる 102 万円は、大正 11 (1922) 年計画において沈澱池導水路が不要であった点が大きく影響し、悠 久山麓から弓町への送水管も大部分が不要となる点も寄与寸る。即

ち、概算で大正 9(1920) 年計画における

沈澱池工事費 一二三, ○三一. 八七

導水路工事費 五四八, 五 $\bigcirc$ 八. $\bigcirc \bigcirc$

送水路工事費 一五四, 八六七. $\bigcirc 0$

予備費 一六七, 九○五.八八注28)

の合計994, 313.87円が大正11 (1922) 年計画では不要となるが、これ らは上述した換算値との差額102万円に近似した額となる。

以上のように大正11 (1922) 年計画は、大正 9 (1920) 年計画の技術的 な問題点を改め、米価で換算し $54 \%$ と半額に近い建設費によって上 水道の敷設を可能とした。このように見ると大正 9 (1920) 年計画は技 術的な問題が予算面での負担となり、“再調” 注29) とされたと言える。 また、大正11(1922) 年計画においてこれだけの低額で上水道計画の 立案がなされたことが、大正11(1922) 年計画において同時に810, 600 円の予算注30)にて下水道の敷設を可能とした理由として挙げられる。

\section{8. 井上二郎に上水道計画を委託した理由}

以上の考察から大正 $9(1920)$ 年の長岡市における上水道計画は、井 上二郎によるものと判明したが、何故、井上がこの時期における長 岡の上水道計画を任されたのか、その点を最後に考えておきたい。

井上は前述のように明治41 (1908) 年以後、陸軍技師として北海道 の旭川、札幌で軍関係の上水道敷設事業に関わり、大正3(1914) 年3 月には依願退職し、以後、陸軍第七師団の建築業務嘱託、陸軍東京
経理部嘱託、旭川区役所水道敷設調査設計嘱託等に就き、富士製紙 本社技師への就職は大正7 (1918) 年11月であった注31)。

即ち、井上が長岡市大正9 (1920) 年計画を委託された大正6 (1917) 年8月の前後、井上は会社組織には属していなかったことになる。ま た、上述のように井上は北海道や福島という、寒冷地における上水 道敷設に豊富な実績を当時、持ったため、長岡における上水道計画 の委託があったものと言えよう。

\section{9 . 明治36 (1903) 年と大正 2 (1913) 年に下水道計画について}

以上のように長岡市における上・下水道の計画は、明治34(1901) 年の段階で上水道、明治36 (1903) 年と大正 2 (1913) 年に下水道、大 正 9(1920) 年に再び上水道、そして、最終的に中島鋭治が上水道、 鶴見一之が下水道を計画した大正 11 (1922) 年計画が実施に至り、昭 和 2 (1927) 年に上下水道が同時に竣功するに至った。この内、本稿 では上水道の大正 $9(1920)$ 年計画と大正 11 (1922) 年計画を詳細に 比較するに至ったが、最後に明治36 (1903) 年と大正 2 (1913) 年にお ける下水道計画の内容も検討しておきたい。

両計画とも記録が未詳のため内容は明らかではないが、完成に至 った大正 $9(1920)$ 年の下水道を検討すると、これは、最終処理を実 施しない未処理の下水を河川に放流寸る略式の下水路と呼心゙るもの でものであった。実際、長岡市以前に完成・着手していた国内にお ける諸都市における下水道はいずれも略式下水路の形式で、最終処 理まで行うことのできた施設は、大正11(1922)年に竣功した東京の 三河島污水処分場と大阪、名古屋における促進污泥法に基づく試験 設備に過ぎなかった注32)。これらの点を考慮すると長岡における明 治36 (1903) 年と大正 2 (1913) 年に下水道2案も同じく、略式の下水路 によるものであったと考えるのが妥当である。

但し、ここで見るべき点は長岡が略式の下水路式であったにせよ、 それが国内でも早い段階における建設計画が持ち上がり、最終的に は昭和2 (1927) 年に至り上・下水道を本邦において初めて同時竣功し た点にあると言える。

10. さいごに

本稿では著者が入手した長岡市における上水道敷設に関する一連 の資料に対し検討を加えたが、明らかとなるのは以下の諸点である。

1) 資料群は大正6 (1917) 年8月から大正8 (1919) 年3月頃までの間に 作成された長岡市の上水道計画で、従来は詳細が紹介されること のなかった、長岡市の大正 9 (1920) 年上水道計画である。

2 ) 大正9(1920)年計画は、井上二郎により作成された。

3 ) 大正 9 (1920) 年計画と実施に至った長岡市の大正11 (1922) 年計画 を比較すると、大正 $9(1920)$ 年計画では取水地を信濃川の妙見、浄 水池を悠久山麓とする2点に著しい相違を確認できる。

4 ) 大正 9 (1920) 年計画と大正11 (1922) 年計画を比較すると、技術、 予算の観点からも大正 9 (1920) 年は問題があり、これらの点を補う 形で大正11(1922)年計画が立案された。

5 ) 長岡における大正 9 (1920) 年計画が井上一依頼されたのは、依頼 当時、井上が会社組織に属さず、寒冷地における上水道敷設の豊 富な実績を持っていたためと考えられる。

以上の考察から、大正 $9(1920)$ 年に建築がなされた長岡市の上水 
道計画のあり方をまとめておきたい。

長岡においては上水道の計画が明治 34(1901) 年、大正 $9(1920)$ 年、 大正 11 (1922) 年の 3 回、下水道も明治 36 (1903) 年、大正 2 (1913) 年、 大正 11 (1922) 年の 3 回ずつ立案された。近代において多くの市町村 で上水道の計画が立てられたものの、成案を見ないものも数々見ら れた。ところで、長岡における第 1 回目の下水道計画の策定となる 明治 $36(1903)$ 年までには、全国においては 9 市町の上水道計画が成 案となったが注33)、この段階で上水道と下水道の優先順位が問題に なり、上水道案が成案に至らなかった事例は存在しない。上水道の 計画が成案に至る場合、問題になるのは多くが過大な予算額であっ た。長岡では当初の上水道計画の出された明治 34 (1901) 年から下水 道との優先順位が理由となり、しかも以後も複数回に渡り問題とな ったが、このような事例は極めて稀である。即ち、都市計画史の観 点から見た長岡における上水道建設までの特色として、地域の特性 による下水道建設との優先順位争いが劇烈であった点を指摘できる。

また、長岡市が大正 9(1920) 年計画を托した井上二郎による生涯 の仕事を概観すると、井上が当初に就職した杤木県では鬼怒川、大 谷川、日光百間堤の工事などを任され、養家に戻った後には手賀沼 の用水や開拓事業に尽力した。これらを見ると井上自身、得意とす る専門分野は水路建設を中心とする治水についで、その結果、上水 道や鬼怒川における水力発電の仕事に従事したとみることができる。 実際、長岡の大正 9(1920) 年計画でも井上が提示した計画案は“延 長五, 七○○間”、即ち $10.3 \mathrm{~km}$ にも及ぶ導水路の計画で、結果とし てこれが過重な建設費の原因となった。上水道の建設において、取 水に対して清浄な源水を給水地もしくは浄水場へ導く考え方は、古 典的な考え方一思想一に根差したものとされる注34)。つまり、井上の 提案は古典的な技術の傾向が強く表れるもので、それ故に近代にお ける技術としては限界が強く意識された。

これに対して中島鋭治による大正 11(1922)年計画は、取水におけ る限界を近代的な技術で乗り越えようとしたものとすることができ る。伏流水の浄水地における取水は長距離の導水路が省かれるため、 工事費においては格段の差が生じ、その差額を結果として下水道に 回すことができたわけである。既に述べたように取水に伏流水を用 いる考え方は中島鋭治が日本では初めて採用し、大正時代末頃から 本格化したとするが注35)、これは特に中島が好んで用いた技術でも ある注36)。即ち、当時、日本における上水道技術の第一人者であっ た中島鋭治による取水における導水に替わる技術の提案、つまり伏 流水の採用は、近代における上水道技術進展の具体的な表れとみる ことができる。

つまり、長岡の上水道における大正 9(1920) 年と大正 11(1922) 年における計画の差異は、土木技術史における格段の展開として位 置付けることができるわけである。

\section{参考文献}

1）長岡市水道局：長岡市上下水道小誌、1927. 3

2) 中島工学博士記念事業会編輯: 中島工学博士記念 日本水道史、 1927.8

3）三谷和夫：昭和前期における手賀沼耕地整理、我孫子市史研究 9、pp. 111 ～149、1985. 3

4）是永定美：土木技師井上二郎と利根川圖志、利根川文化研究 $12 、$ pp. 1 16、1997. 1

注1）参考文献 1） $1 \sim 3$ 頁
注 2) 長岡市: 長岡市史 通史編下、467 頁、平成 8 (1996). 3

注 3）参考文献 1)

注 4）後述するように当該の資料は散逸した結果、書肆を通して筆者が入手 するに至ったものと考える。

注5）(1)平山：長岡市の大正時代中期における上水道計画資料と予算額見積に つい、長岡造形大学紀要2、30 32 頁、平成 $17(2005) .3$

(2)平山: 大正 $9(1920)$ 年の長岡市上水道計画の概要「水道タンク」はなか った大正 $9(1920)$ 年の上水道計画、長岡造形大学紀要3、71 86 頁、平成 18(2006). 3

注 6）長岡商業会議所 : 長岡商工人名録 大正十四年、63 頁、大正 14(1925).4

注 7）参考文献 3） 114 116 頁

注 8) 参考文献 2) 496 頁

注 9）参考文献 2) 495 頁

注10) 平山：大正 5(1916) 年三条町上水道計画について三条市上水道の調査 研究 その 5、日本建築学会北陸支部研究報告集 53、461 462 頁、平成 22 (2010).7。なお、この計画は実施に至っていない。

注11）福島県石城郡平町役場：平町上水道誌、193 頁、大正 15 (1926). 4

注12) (1)猪野三郎監修: 大衆人事録第 3 版、イ 14 頁、昭和 5(1930).7

(2)猪野三郎監修: 大衆人事録第 7 版、イ 16 頁、昭和 7 (1932).8

注13）井上薰 : 尋衫られるままに一故郷との八十年を回顧する一、我孫子市史 研究 9、25 頁、平成 2(1990). 3、では井上二郎の子である薰が、井上の仕 事について“後ですけれども新潟、これも軍隊ですが、そういう所で水道 や水力発電の建設に関係していました”とするが、新潟県内で井上による 軍関係の仕事は確認できていない。

注14）新潟日報社：新潟日報、大正 6 (1917).8/22, 2 頁

注15）新潟日報社: 新潟日報、大正 6 (1917).9/30, 2 頁、10/2, 2 頁、10/31, 2 頁

注16）参考文献 1） 4 頁

注17）参考文献 1） 4 頁

注18）参考文献 1） 10 頁

注19）参考文献1） 4 5 頁

注20）参考文献2）142頁

注21）1間は $1.8 \mathrm{~m}$ で計算。地図上の距離でもほぼ合致する。

注22）予備費の167, 905. 88円を総額から引いた経費に対する割合は $27 \%$ とな

る。なお、百分率はいずれも小数点以下 1 桁を四捨五入した。以下同様。

注23）参考文献1）4頁

注24）参考文献2）156 160頁

注 25）参考文献 1） $23 \sim 25$ 頁

注 26）参考文献 1）2 頁

注27）近藤義質：お米の明治百年史、全国食料事業協同組合連合会、昭和 44 (1969). 4、「米穀史年表」235～236頁。大正 7 (1918) 年の数值は同年7 月以後におけるいわゆる米騒動による米価暴騰の影響を受ける。見積が行 われたのは、10)『その他書類』によれば大正 7 (1918) 年4、5月であるた め、大正6 (1917) 年の石当り米価は19.80円と、大正12 (1923) 年は32.38円を 比較した。つまり、この間、米価による換算で物価は1.64倍となる。

注28）いずれも2）『予算書』“総工事費”の項目

注 29）参考文献 2）429 頁

注 30）参考文献 1）2 頁

注 31）参考文献 3） 114～116 頁

注 32）参考文献 2) 172 頁

注 33）参考文献 2） $166 \sim 172 、 727 \sim 827$ 頁

注 34）鯖田豊之：水道の思想、中公新書 1297、26 38 頁、平成 8(1996).4 注 35）参考文献 2) 142 頁

注 36）平山：長岡市水道施設には何故、水道タンクが建設されたのか、長岡 造形大学紀要 4、51 54 頁、平成 19(2007). 3 


\section{STUDY ON THE WATERWORKS PLAN IN THE MIDDLE OF TAISYO ERA OF NAGAOKA CITY}

\section{Ikuo HIRAYAMA*}

* Prof., Faculty of Design, Nagaoka Institute of Design, Dr.Eng., Dr.Design

This article examines the series of documents about the waterworks facilities in Nagaoka city, which the author obtained, and following points are clarified.

The document introducing this time is the waterworks plan of Nagaoka city 1920 which had produced from A ugust 1917 to $M$ arch1919, and the detail of the plan has never been introduced. The plan of 1920 was produced by M r. Jiro Inoue who had worked for Fuji-Seisi. Comparing between the plan of 1920 and the plan of 1922, there are two remarkable differences. They are to have assumed the water intake point at M youken of the Shinano River and to have arranged the clear water reservoir at the foot of the mountain Y ukyusan in the plan of 1920. Since the plan of 1920 had difficulties in terms of the technique and the budget, in order to improve them, the plan of 1922 was drawn up.It is considered that M r. Inoue was requested to produce the waterworks plan of Nagaoka city 1920 because he was an expert of the waterworks facilities in cold regions and he was freelance in those days. 